Technological University Dublin

DÜBLIN

ARROW@TU Dublin

\title{
A new era for reuse social enterprises in Ireland? The capacities required for achieving sustainability
}

Gerard Doyle

Technological University Dublin, gerard.doyle@tudublin.ie

Follow this and additional works at: https://arrow.tudublin.ie/beschspart

Part of the Engineering Commons, and the Sociology Commons

\section{Recommended Citation}

Doyle, G. (2019) 'A new era for reuse social enterprises in Ireland? The capacities required for achieving sustainability', Journal of Resources, Conservation and Recycling, 149, 65-74. DOI: 10.1016/ j.resconrec.2019.05.012

This Article is brought to you for free and open access by the School of Transport Engineering, Environment and Planning at ARROW@TU Dublin. It has been accepted for inclusion in Articles by an authorized administrator of ARROW@TU Dublin. For more information, please contact arrow.admin@tudublin.ie, aisling.coyne@tudublin.ie,gerard.connolly@tudublin.ie. Funder: ICOS Golden Jubilee Trust Fund 


\title{
A new era for reuse social enterprises in Ireland? The capacities required for achieving sustainability
}

\author{
Gerard Doyle \\ Technological University of Dublin, Ireland
}

\section{A R T I C L E I N F O}

\section{Keywords:}

Capacity

Community

Reuse

Social enterprise

Sustainability

\begin{abstract}
A B S T R A C T
The conventional linear relationship between production and consumption is no longer sustainable. A key component of the transition towards a more sustainable society is the continuation in use of products for longer and the development of a repair and reuse culture. Reuse social enterprises contribute to addressing a range of environmental, economic and social issues facing urban areas. This paper is concerned with, firstly, the motivations for citizens to establish reuse social enterprises in Ireland. Secondly, the paper examines the factors that contribute to reuse social enterprises in Ireland becoming sustainable.

The research points to the necessity of reuse social enterprises possessing: individuals with both strategic and operational expertise, appropriate facilities and adequate funding to commence operations. The research highlights the crucial role that the manager of the enterprise performs in engaging with state agencies, the community and other stakeholders. The theoretical framework detailed in the paper needs to take into account the challenges associated with being located in urban areas which reuse social enterprises encounter.

It is incumbent upon the Irish State to develop policies to assist individuals who are interested in establishing reuse social enterprises. These policy areas include procurement, the introduction of additional producer responsibility initiatives and the amendment of the tax system to encourage reuse.
\end{abstract}

\section{Introduction}

The member states of the European Union (EU) are encountering a crisis in terms of resource availability, use and disposal of products (Ellen MacArthur Foundation, 2011). Within the EU, material recycling and wastebased energy recovery secures approximately 5 per cent of the original raw material value (Ellen MacArthur Foundation, 2015). Arising from current high levels of personal consumption and disposal, resources in Ireland are being depleted at an unsustainable rate (Doyle and Davies, 2013). Within the $\mathrm{EU}$, each person consumes, on average, 13.3 tonnes(t) of materials annually (EC, 2011). Much of this is being discarded, with an average waste production rate of $5 \mathrm{t}$ of total waste per person annually (EC, 2011).

The conventional linear relationship between production and consumption is no longer sustainable (Moreau et al., 2017). For the switch from a linear to a more sustainable use of goods and products to be realised, citizens must alter their consumption patterns to consume within sustainable limits for the benefit of the environment and to ensure an acceptable standard of living for future generations (Jackson, 2011). A key component of the transition towards a more sustainable society is the preservation of products in use for longer and the development of a repair and reuse culture (Ellen MacArthur Foundation, 2015).

Reuse social enterprises contribute to addressing a range of environmental, economic and social issues facing urban areas and regions (Aiken and Slater, 2007; Bichard, 2006; and Vickers, 2010).
This paper is concerned with, firstly, the motivations for citizens establishing reuse social enterprises. Secondly, the paper examines the factors that contribute to reuse social enterprises becoming sustainable. The core question being addressed is:

What capacities enable reuse social enterprises in Ireland to become sustainable?

A subsidiary question is:

What motivates citizens to establish reuse social enterprises?

Section two of this paper examines the key concepts underpinning the research. The third section focuses on the motivations for communities and groups of individuals to establish reuse social enterprises, followed by the theoretical framework for reuse social enterprises in section four. The methodology for the research undertaken will then be outlined in section five. The penultimate section details the research findings. The final sections of the paper contains the discussion and conclusion.

\section{Concepts}

\subsection{Social enterprise}

Social enterprise has been defined in many different ways. Indeed, 
at European level, there is no universally accepted definition of a social enterprise (GHK, 2006; Nicholls and Teasdale, 2017). However, the number of definitions of what constitutes a social enterprise reflects the diverse understanding of what a social enterprise actually is.

The Forfás (2013) definition is widely used:

An enterprise that trades for a social/societal purpose, where at least part of its income is earned from its trading activity, is separate from government, and where the surplus is primarily reinvested in the social objective.

The strength of the Forfás definition is that it states that social enterprises have social and economic objectives. The principle of community ownership is alluded to but it does not place significant weight on the fact that social enterprises are managed differently to private enterprises in that they are democratically governed by a group of people on behalf of a community, rather than by shareholders seeking a return on their investment.

To address the above shortcoming in the Forfás definition, Molloy et al. (2000) proposes a definition which emphasises that social enterprises are democratic entities which are controlled and owned by either their members or by the communities which they serve (Amin et al., 2002). This definition incorporates co-operatives, associations and mutuals.

\subsection{Waste, reuse and the circular economy}

Gutberlet (2008) draws attention to the subjectivity of waste. However, some definitions are more dominant than others (Gutberlet, 2016). The dominant definition of waste views it as something that is not wanted and which the owner intends discarding (Pongracz and Pohjola, 2004). This perspective sees waste as a nuisance (Pongracz and Pohjola, 2004; Davies, 2002). The current situation needs to be transformed from viewing waste as a liability to viewing it as a resource (Ackerman and Mirza, 2001).

According to Miller et al. (2017: p.2), 'reuse occurs when an owner continues to use a material for the same or an alternative use, or when the item is transferred to someone else for continued use. In both cases, the item is still a resource and is not considered waste. At some point, everyone has things that are no longer useful to them, but these items, which still have value, may be useful to others and can therefore be reused'. Similar to the concepts of waste and reuse, the circular economy is a contested term (Bocken et al., 2017)

\subsection{Capacity}

The concept of capacity refers to the ability of members of a community or indeed the community itself to make changes by harnessing the resources at their disposal either individually and collectively (Middlemiss and Parrish, 2009).

There are a range of motivations for establishing reuse social enterprises which are outlined in the next section.

\subsection{Sustainability}

According to Nyssens (2006b), the corporate sector's discourse on sustainability - which is measured in terms of profit maximisation, productivity and competitiveness - has a significant influence on how the sustainability of social enterprises is framed. This discourse on sustainability does not fit well with the diversity of social enterprises in the Ireland, many of which could never attain financial sustainability (Crossan and Van Til, 2008). Indeed, it is the view of Chan et al. (2017) that the majority of social enterprises will never attain financial sustainability due to their combination of activities and because of their location in disadvantaged communities. The concept of sustainability needs to be broadened to account for social, environmental and economic goals (Boschee and McClurg, 2003; and Ridley- Duff and Bull, 2016).
Moreover, social enterprises' sustainability should not be defined and measured solely in financial terms. Instead, it should be defined in terms of the extent to which a social enterprise achieves a combination of social, financial and environmental sustainability. These different forms of sustainability may be defined as follows: social sustainability is the extent to which a social enterprise realises its social mission; financial sustainability is the extent to which a social enterprise can meet its operational costs from a combination of grant and traded income, and input from volunteers; and environmental sustainability is the extent to which the social enterprises activities can continue without having a negative impact on the physical environment (Doyle, 2019).

\section{Motivations for establishing re-use social enterprises}

The principals of reuse social enterprises have different motives for establishing them (Taylor, 2008., Nicholls, 2006; and Seanor et al. (2013)). Reuse social enterprises have a number of social objectives that tend not to be met by the state or the private sector (Lucklin and Sharp, 2003). These include the provision of employment and training (Lucklin and Sharp, 2005). They also serve as a source of goods to low income households (Lucklin and Sharp, 2005). In addition to realising social objectives, environmental protection and economic regeneration are motives for the formation of reuse social enterprises (Davies, 2007). With regard to employment, the jobs provided by reuse social enterprises augment the skills and confidence of individuals who were previously long-term unemployed (Brennan and Ackers, 2004). In relation to environmental motives, the desire to reduce the level of waste going to land fill is the primary motive for principals in establishing reuse social enterprises (Davies, 2007). Reuse social enterprises are established to fulfil a combination of environmental, economic and social justice objective (King and Gutberlet, 2013)

Regarding ideological motives, a number of commentators allude to the formation of reuse social enterprises to compensate for the failure of the private sector to stem the increase in the generation of waste in Western societies (Ahmed and Ali, 2004; Price and Joseph, 2000). Reuse social enterprises have the potential to reduce resource use and waste generation (Belk, 2007).

\section{Theoretical framework}

This section of the paper firstly examines the challenges that reuse social enterprises face. It then proceeds to outline the capacities required for their successful implementation.

The leadership of reuse social enterprises have a tendency not to pay sufficient attention to the external environment or to strategic development (Brook Lyndhurst, 2007). This can be further compounded by a tendency of the leadership of social enterprises to not have business acumen. According to Brook Lyndhurst (2007) another challenge reuse social enterprise can encounter is not affording sufficient attention to developing management processes. This can lead to a lack of consistency in the quality of products (Brook Lyndhurst, 2007).

The above can stymie the capacity of reuse social enterprises to achieve financial sustainability (Brook Lyndhurst, 2007). Rather than solely concentrating on the capacity of reuse social enterprises, Amin et al. (2002) assert that the demographic profile of communities in which social enterprises are located has a significant impact on their capacity to become financially sustainable. Indeed, communities which would benefit most from the presence of reuse social enterprises tend to provide less of a conducive environment for social enterprises to successfully operate than more affluent ones (Amin, 2009).

Furthermore, Hines et al. (2008) assert that the major challenges which reuse social enterprises encounter emanate from the environment in which they operate. These challenges include demands placed on them by the regulatory environment, having to operate in a competitive environment against investor-owned businesses. This can be further compounded by social enterprises having insufficient resources 
to employ a management team to increase the size of the business.

Access to appropriate facilities of sufficient size and appropriate location can present a challenge to the financial sustainability of reuse social enterprises (Brook Lyndhurst, 2009). Accessing appropriate sources of finance is deemed a significant barrier to reuse social enterprises achieving financial sustainability. Brook Lyndhurst (2006) believe the tendency of reuse social enterprise to rely on grant finance prevents them from innovating and increasing scale. An alternative perspective on grant finance is put forward by Doyle (2009). He asserts that reuse social enterprises can fulfil the objectives of a number of state agencies and consequently should be awarded state funding.

Therefore, an examination of the capacities critical for reuse social enterprises to become sustainable could assist communities and policymakers alike in the establishment of reuse social enterprises.

A theoretical framework is employed which encompasses individual, structural, cultural and infrastructural capacities that are interlinked. This theoretical framework informed by research conducted by Emery and Flora (2006), Porritt (2007), Seyfang (2014), Middlemiss and Parish (2009), and Pringle (2015).

In particular, the theoretical framework is underpinned by the Community Capitals Framework (Emery and Flora, 2006). According to this framework, community change can be understood through analysing the following types of capital that exist within a community:

- Natural capital refers to the level of assets associated with a particular area. These include amenities, scenery, natural amenities and geographic isolation.

- Cultural capital refers to the how residents of a community comprehend society. It influences how and whether people are listened to within a community.

- Human capital is associated with the level of skills and expertise that residents possess. This is required to bring about change.

- Social capital refers to the degree of inter-connectedness between residents and organisations in an area.

- Political capital refers to the level of power, and connections to resources and organisations. It also refers to the ability of people to articulate their perspectives.

- Financial capital is associated with the level of financial resources which can be invested in a range of activities associated with community endeavour.

- Built capital refers to the infrastructure which is necessary for a community to organise and implement its plans.

The Community Capital Framework informs Pringle's theoretical framework. Pringle (2015) cites four categories of capacity which constitute the theoretical framework. The first is individual capacity. Pringle (2015) defines individual capacity as the level of skills, values and finance that individuals within a community possess which can assist in the formation of sustainable development initiatives - focusing on renewable energy. Middlemiss and Parrish (2009) assert that an individual's social context shapes their capacity to initiate sustainable development initiatives. The presence of leaders within communities, who have a clear vision for the development of reuse social enterprises, is critical to their successful establishment (Brook Lyndhurst, 2007). Successful reuse social enterprises tend to be characterised by possessing effective leaders who have the capacity to secure resources (Connett and Sheehan, 2001). Brook Lyndhurst (2006) identify sustainable reuse social enterprises as possessing effective managers, management structures and processes.

The second is the structural capacity of a community. This focuses on the culture and values pertaining to organisations within a community that have an influence over communities' efforts to implement sustainable development initiatives (Middlemiss \& Parish, 2009). Local development agencies, politicians and state agencies are included in this category (Pringle, 2015). The presence of community organisations and supportive state and local development institutions can contribute to a range of barriers being addressed (Pringle, 2015). State agencies that are supportive towards reuse social enterprises can have a positive influence on the outcomes of reuse sustainable development initiatives (Dedehouanou, 1998). However, to maximise the supportive role they can perform requires greater integration between various departments of local government (Yousefpour et al., 2012). Even if there is greater collaboration and integration between departments in local authorities, the framework proposed by Pringle does not acknowledge that some local authorities are more supportive towards working with reuse social enterprises (Resource Futures, 2009). Moreover, some local authorities are not receptive towards bottom-up approaches to addressing waste via the development of reuse social enterprises (Resource Futures, 2009).

The third is Infrastructural capacity. This refers to the stock of infrastructure that is present in communities which are conducive to the drive to promote sustainability (Pringle, 2015). Adequate space enables reuse entities to store discarded material and products which, over time, could generate income (CWIN, 2016). This study emphasises the importance of the establishment of retail units to sell reuse products to the public (CWIN, 2016). The proximity of reuse facilities, including retail units, to residential areas, contributes to the donation and purchase of reuse products (Steel, 1996).

Finally, cultural capacity refers to the level of commitment and openness to sustainability that exists within a community (Pringle, 2015). Cultural capacity is influenced by the historical context towards sustainability (Pringle, 2015) (Fig. 1).

Research indicates that the personal qualities of managers or leaders of social enterprises tend to differ from those of investor-owned businesses (Ridley-Duff and Bull, 2016). The former style of leadership is underpinned by values such as humility, professionalism and calmness (Collins, 2001). Indeed, leaders of social enterprises with these qualities contribute to their sustainability (Jackson et al., 2018). Effective managers of social enterprises require the following attributes: the ability to develop a vision for the organisation; the interest and capacity to develop employees and volunteers; a commitment and ability to promote democracy within their social enterprise, and the capacity to benefit the community which the social enterprise serves (Aziz et al. (2017); and Van Dierendonck and Nuijten, 2011). The governance structures of social enterprises require individuals with expertise in finance and the capacity to realise the social mission (Mason and Royce, 2008).

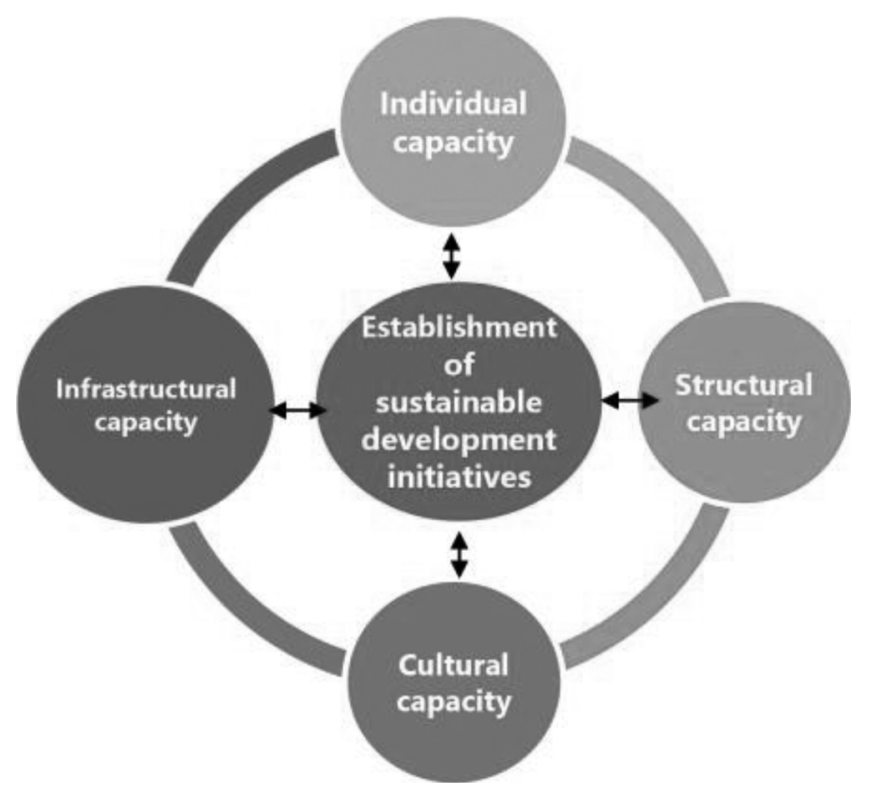

Fig. 1. Theoretical Framework, adapted from Pringle (2015). 


\section{Methodology}

\subsection{Case selection}

Seven cases were selected in Ireland for this piece of research. The social enterprises were selected because of their varying perceived reasons for establishment, varying models of operation and their core organisational objectives. Regarding different models of operation, the majority receive state funding from national programmes to employ staff, while a minority are dependent on securing contracts from local authorities and state agencies to deliver services.

The seven social enterprises are:

- Boomerang recycling located in the northside of Cork city;

- Kingdom Revamp based in Castleisland, County Kerry;

- Recycle IT located in Clondalkin, Dublin;

- Recreate based in Ballymount, Dublin

- Rediscovery Centre, situated in Ballymun, Dublin;

- WeShare whose principals live in Dublin;

- 4Rs is based in Derry city;

They were selected because of their similar size. For example, none of them employ more than fifteen staff. In addition, each of them focuses on a relatively small urban area compared to their counterparts in other European countries. Indeed, none of them operate on a regional basis.

The table below (Table 1) details the items and materials that are reused by the social enterprises.

\subsection{Methods}

Twelve semi-structured interviews were held with key individuals who are either managers, voluntary directors or volunteer leaders associated with the above seven reuse social enterprises. A few managers of reuse social enterprises said that their respective management committees would not have time to participate in a focus group. The interviews were held either in person or over the phone.

\subsection{Data collection and coding}

A list of trigger questions was used to guide the interviews, and some additional questions were posed, depending on each interviewee's responses. All interviews were audio-recorded and transcribed verbatim.

\subsection{Analysis}

Qualitative thematic analysis was employed to formulate themes from the transcripts (Braun and Clarke, 2006). The process entailed reading each of the transcripts a number of times in order to become familiar with the data. The text of each of the transcripts was then coded.

Table 1

Material/items reusedss.

\begin{tabular}{ll}
\hline Reuse social enterprise & Item/material \\
\hline Boomerang recycling & Mattresses \\
Kingdom Revamp & Furniture \\
Recycle IT & Waste electronic and electrical equipment \\
Recreate & Paper, cardboard and fabrics \\
Rediscovery centre & Bicycles, clothes, furniture and paint \\
WeShare & Household and personal items \\
4Rs & Furniture and electrical goods \\
\hline
\end{tabular}

\section{Findings}

The research findings pertain to interviews and focus groups with individuals associated with reuse social enterprises and policy makers. A number of themes are employed to categorise the research findings. The themes are: getting started; organisational development; management; resources; sustainability; relationships; values and policy. The research findings also identify the importance of planning to the establishment of a sustainable reuse social enterprises. The research findings associated with the planning phase is not covered in this paper as it is covered extensively in the literature. The research findings also point to how a culture of consumerism as well as current state policy both serve as a barrier to reuse social enterprises becoming sustainable.

In turn, each of the themes includes a number of sub-themes.

\subsection{Getting started}

\subsubsection{Motives}

Interviewees speak of there being multiple motives for establishing reuse social enterprises. The achievement of social objectives are the most commonly cited motives for the establishment of reuse social enterprises. These social objectives are in the main concerned with both employment creation and strengthening the skills of unemployed individuals with a view to securing employment. Furthermore, a number of the social enterprises target their recruitment at marginalised social groups and disadvantaged communities.

"The northside of $\mathrm{X}$ being very high in youth unemployment. It's somewhere to go when they come out of prison."

Other social objectives interviewees cite include: the supply of lowcost furniture to families experiencing poverty; addressing inter-generational unemployment and reducing criminal recidivism and antisocial behaviour.

An environmental motive is considered the primary reason for the establishment of two reuse social enterprises. This motive encapsulates varying ideological perspectives from reducing the incidence of illegal dumping of harmful waste to treating waste as a resource.

"It was before there was any legislation involved in dealing with the waste that we deal with here and around the same time, there had been huge issues with illegal dumping of fridges particularly."

Although, the overwhelming majority of social enterprises cited one primary objective, they each had subsidiary objectives.

"It was a dual motive and it would be environmental and social."

The table below (Table 2) provides an overview of the incidence of each of the primary motives for establishing reuse social enterprises (Table 3).

\subsubsection{Pre-development}

Half of the interviewees acknowledge the importance of undertaking a feasibility study and business plan prior to the commencement of operations.

"We were so glad that we did a business plan and we learned a lot from a social enterprise in the UK. We believe that this prevented us from making a load of mistakes."

Table 2

Primary motive establishment reuse social enterprise.

\begin{tabular}{ll}
\hline Primary motive & Number of social enterprises \\
\hline Fulfilling social or economic objective & 4 \\
Safeguarding the environment & 2 \\
Promoting an alternative economic system & 1
\end{tabular}


Table 3

Origins of social enterprise.

\begin{tabular}{ll}
\hline $\begin{array}{l}\text { Category organisation that established social } \\
\text { enterprise }\end{array}$ & $\begin{array}{l}\text { Number of social } \\
\text { enterprises }\end{array}$ \\
\hline $\begin{array}{l}\text { Community and voluntary organisations } \\
\text { Local development companies (LDCs) }\end{array}$ & 3 \\
Local authorities & 3 \\
\hline
\end{tabular}

These are multi-sectoral partnerships that deliver social inclusion initiatives, community and rural development programmes, labour market activation and social enterprise services. LDCs support more than 15,000 community groups and 173,000 individuals annually through $€ 330$ million of state-funded programmes. www.ildn.ie.

Indeed, one interviewee refers to the time and resources invested in doing a business plan as reducing the risk of the social enterprise failing.

"I have seen social enterprises get into all sorts of problems from not taking the time to do a plan."

\subsection{Organisational development}

\subsubsection{Strategic expertise}

According to a small number of interviewees, directors who have the requisite knowledge and expertise are required to ensure the organisation fulfils its mission. The same cohort of interviewees refer to the board of a social enterprise having directors with the following expertise: business expertise; knowledge of employment law; social enterprise expertise; knowledge of governance and expertise in the relevant social enterprise activity.

Regarding the level of expertise required by community representatives serving as directors, interviewees express two contrasting points of view. One perspective speaks of these directors having the requisite expertise prior to participating on a board. The other perspective considers that the role of the social enterprise is to provide community representatives with the necessary skills and expertise to effectively participate on a board. By undertaking the latter course of action, this can contribute to boards of social enterprises achieving balanced representation.

\subsubsection{Operational expertise}

According to the overwhelming majority of interviewees, staff with expertise and skills relating to their respective social enterprise activity perform a central role in the social enterprise fulfilling its mission.

"I've been in the recycling industry for a number of years. I've been to a number of countries and it was all within the waste recycling sector. The knowledge acquired certainly is having a positive impact on the social enterprise."

Interviewees detail a number of benefits from employing staff with expertise relating to the social enterprise activity.

- The opportunity to train formerly unemployed staff a range of skills on site.

- The capacity to diversify into producing new products which can strengthen its financial sustainability.

- Knowledge of environmental regulation reduces the reliance on external consultants.

- Knowledge of the markets enables social enterprises to secure the best prices for recycled material.

A number of interviewees cite other types of expertise as being key to maintaining a sustainable social enterprise. These include: financial management; marketing; and the capacity to measure impact; generic business expertise and logistics.
"You would also need somebody that would have a good business acumen..."

"The key skills in getting the social enterprise up was financial management, business and knowledge of the industry. They are key skills in keeping the social enterprise successful."

Four interviewees are of the opinion that reuse social enterprises encounter a greater number of challenges than investor-owned businesses. These include: being restricted to employing lower skilled staff; barriers to staff acquiring new skills; the challenging behaviour of a proportion of staff that were formerly unemployed; the reluctance of a proportion of staff to address their literacy issues, and the requirements of funders. Consequently, two interviewees speak of the importance of social enterprises employing key staff who have experience of supervising staff that were formerly long-term unemployed.

\subsubsection{Equilibrium}

Several Interviewees acknowledge how social enterprise, in aiming to realise a social objective while simultaneously achieving financial sustainability, can encounter a number of organisational challenges. According to two interviewees, reuse social enterprises can encounter staff productivity issues when they either diversify into new market niches or increase the level of activity. The same interviewees acknowledge that a balance needs to be achieved in acknowledging the issues certain staff may experience, while at the same time expecting staff to become more productive after receiving supports.

"We had quite a low burden of financial administration because we have a couple of big customers. We've gone from that model into servicing and charging householders. This has placed more demands on our staff."

Three interviewees refer to the challenge social enterprises encounter in realising their environmental objectives when their main funder demands more of a focus on generating income.

"It's maybe moving into what you would call a normal business, objectives of driving the sales side and they're not able to focus at all or use the environmental message to explain what they do."

\subsection{Management}

The theme of management is covered under the five sub-themes below.

\subsubsection{Committed}

Persistence and tenacity are key attributes of managers, according to four interviewees. One of them considers managers who are passionate about improving the lives of marginalised groups as being another important attribute.

"Constant dripping water on a stone. It will wear the stone eventually, if you keep at it, your message will get across."

They acknowledge how these attributes are pivotal to achieving the objectives of reuse social enterprises. In particular, persistence and tenacity are considered necessary attributes to secure resources, including facilities.

\subsubsection{Inclusive}

According to two interviewees, managers who create an inclusive work environment tend to gain the co-operation of staff. One interviewee emphasises the priority that he placed on creating a team. This entails informing all of the staff and participants of the sales targets. They are informed of how attaining the targets ensures that the social enterprise is financially sustainable for another year.

"I've actually got buy-in from all the individuals and I tell them what we are trying to do, I tell them why I'm trying to do it. I tell them the 
numbers that we have to achieve, the reasons why we have to achieve it, and they feel a part of the project."

One interviewee mentions that the manager can communicate to create an inclusive work environment. Two interviewees acknowledge how holding formal communication is not as effective an approach as holding informal meetings with many of the staff of reuse social enterprises.

The point is made that many of the staff are encountering a range of challenges to work either part or full-time. Two managers comment on how managers need to be mindful of the background of some of the staff.

"The key thing to addressing these challenges is good common-sense management."

According to two interviewees, a successful manager of a reuse social enterprise needs to have good inter-personnel skills. One interviewee makes the point that management styles practiced in the private sector tend not to be suited to reuse social enterprises.

\subsubsection{Proactive}

Two interviewees acknowledge the role managers play in seeking resources for reuse social enterprises. They both mention that some reuse managers proactively seek resources from a number of funding bodies. Interviewees comment on managers requiring the capacity to seek resources from different funding bodies. This can often require the message being altered to suit the funder.

\subsubsection{Influential}

Three interviewees emphasise the importance of managers being able to influence different stakeholders to assist in developing the reuse social enterprise. With regard to staff, managers aim to motivate workers who can sometimes exhibit challenging behaviour.

"I suppose a key role is to motivate staff. They are the frontline and the people who are selling the concept to the public which is very critical."

The same interviewees refer to managers having the ability to influence potential benefactors, including local authorities, to provide support. In particular, the manager needs to convince senior local authority officials that the reuse social enterprise is viable and attains the objective it sets.

"Convincing local authority that this was something that was viable and that could be supported."

\subsubsection{Empathic}

Two interviewees emphasise how their having experienced discrimination allows them to be more effective managers. They spoke of this having an influence over how the social enterprise operates.

\subsection{Resources}

\subsubsection{Facility}

Five interviewees acknowledge how a facility can either enable the social enterprise to attain its objectives or can stymie it. Two interviewees comment on how acquiring a facility, at a reasonable rent, can strengthen the financial sustainability of the reuse social enterprise. In relation to design, if the facility has scope for either the building of an extension or inserting a mezzanine floor, this can enable the social enterprise to diversify its operations and handle a greater volume of material.

"We're recently putting in another floor on it in order to increase the floor space in there to do a bit more of in-house, if you'd like to call it scavenging, or you know extracting components and so on, so we're gearing up better for that as well."
For two social enterprises, the lack of space in its facility results in having to turn down the offer of valuable discarded goods.

“There are times there where we've had to just pass material on because we had no storage capacity and we would have made more money out of it if we had been able to do a better space."

This is adversely impacting on the financial sustainability of both social enterprises.

In addition to ample space, three interviewees comment on how the location of a facility has a bearing on a social enterprise attaining its objectives. One interviewee refers to the inability of securing a facility in its targeted marginalised area. The same person comments how this made it more difficult to promote recycling in its targeted marginalised area.

"Ideally, we would have wanted a premises within the Rapid Area that we were set up to serve but there was nothing available, there was no premises whatsoever up there..."

Three interviewees comment on how the location of a facility has a bearing on the financial sustainability of the social enterprise.

"We were struggling last year while we were up in the industrial unit, we're now on the street and we're hitting our targets in terms of money."

One interviewee acknowledges how the design of a facility can impact on staff morale.

“The environment wasn't great above either because we were in an industrial unit, there was no windows, there was no heating, you know this type of thing."

The establishment of reuse facility beside civic amenity centres would increase reuse rates in Ireland, according to one interviewee.

"It's providing covered space, it's making it a priority in civic amenity sites. This entails properly protecting equipment and goods that go into civic amenities so they can be reused."

\subsubsection{Credibility}

Two interviewees speak of how they believe some senior local authority officials are sceptical of the capacity of reuse social enterprises to provide an efficient service on behalf of local authorities. One interviewee refers to how securing national funding enhanced the reputation of the social enterprise among senior local authority personnel. According to two interviewees, a social enterprise has to gain credibility.

"Now we have established a good track record, which is good but had to be earned, and so that adds to your credit when seeking to expand."

\subsection{Sustainability}

\subsubsection{Cost base}

According to a number of interviewees, managers of reuse social enterprises are noting a significant increase in operational costs.

\subsubsection{Labour subsidy}

Five interviewees acknowledge how funding from the Pobal Community Services Programme (CSP) $)^{1}$ is critical to the financial

\footnotetext{
${ }^{1}$ The Community Services Programme (CSP) supports community companies and co-operatives to deliver local social, economic and environmental services that tackle disadvantage. It provides funding as a contribution towards the cost of employing a manager and full-time equivalent (FTE) positions. https://www. pobal.ie/programmes/community-services-programme-csp/.
} 
sustainability of social enterprises. (Pobal allocates funding on behalf of the Government and the EU to community companies and co-operatives to support social inclusion and local development.) The same interviewees emphasise the negative impact on the financial sustainability of social enterprises of the Pobal CSP wage grant not being pegged to increases in the national minimum wage.

"You see, the minimum wage when we started was $€ 8.65$ and now it’s $€ 9.55$, the government don't pay the difference."

The same interviewees assert that the Pobal CSP wage grant needs to be increased to keep pace with the minimum wage. Furthermore, three interviewees believe that Pobal needs to reinstate the material grant.

\subsubsection{Labour market}

Five interviewees acknowledge that with a significant reduction in unemployment levels, social enterprises are not able to provide the wage levels being offered by investor-owned companies. Consequently, reuse social enterprises are less likely to attract skilled staff in times of economic prosperity than during the period of the economic downturn when unemployment was far higher.

A proportion of social enterprises utilise employment activation programmes to provide the necessary labour. A number of interviewees comment that this cohort can experience a range of personal issues which can affect their ability to be productive.

"So the people who are being taken onto the Tús programme would have significantly more issues than we would have seen two or three years ago."

\subsection{Relationships}

\subsubsection{Community}

Four interviewees comment on the pragmatic reasons reuse social enterprises engage with their respective communities. Prior to a reuse social enterprise commencing operation, community engagement facilitates addressing mis-information pertaining to a new operation.

"We had open days, we used the council website, showing people what we done, we done small focus group to get the message across, we've been to all of the community groups and we invited all the councils here to let them see what we were doing."

\subsubsection{Parent structure}

A number of reuse social enterprises are controlled by a parent organisation, according to several interviewees. These can be local development companies or community organisations. Two interviewees mention how parent structures initiate the process of establishing a reuse social enterprise. One interviewee emphasises that without a parent structure, the reuse social enterprise would not be formed. The parent structure provides a range of expertise and finance which allows the reuse social enterprise to be formed, a facility to be leased and a manager to be hired before state funding is drawn down. For one interviewee, the reputation of the parent structure with a number of local authorities proves critical to the reuse social enterprise securing public contracts.

"They had the reputation which we would not have had and that was a big thing at the start."

One interviewee acknowledges how a parent structure can cushion cuts in the state funding allocated to a reuse social enterprise.

In the table below (Table 2) the reuse social enterprises are categorised according to the type of organisation responsible for their establishment.

\subsubsection{Network}

Two interviewees acknowledge the wide network of business relationships with individuals that they have cultivated from working in the waste industry.

"I know a lot of people in waste industry who I can get advice from on a range of matters, including where to get the best price for recycled material."

Two interviewees note that a number of reuse social enterprises are networking in a number of ways. Firstly, more experienced managers of reuse social enterprises provide advice, informally, to less established reuse social enterprises dealing with the same discarded goods. Secondly, reuse social enterprises can transfer discarded goods to other reuse social enterprises, if the former is operating at full capacity. This ensures that reuse social enterprises do not have to refuse discarded goods.

\subsubsection{State involvement}

The state interacts with reuse social enterprises in several different ways, according to five interviewees. Local authority officials serve on the management committee of a number of reuse social enterprise. Three interviewees emphasise how having them on their management committee enables a range of supports and resources to be acquired from local authorities. One interviewee mentions how local authority staff on the management committees act as a conduit to the local authority. Indeed, two interviewees comment that the assistance they receive from the local authority is a prerequisite for the formation of their reuse social enterprise.

"Without the support from the local authority, the project would not have happened."

\subsection{Values}

\subsubsection{Solidarity}

Solidarity exists within and between reuse social enterprises. Regarding the former, interviewees note how many staff are motivated to contribute to creating a more ecologically sustainable society by working in reuse social enterprises. Consequently, they are prepared to work for less remuneration than they could gain in the private sector. One interviewee refers to how workers are ideologically motivated to work in reuse social enterprises. However, two interviewees acknowledge that it can be difficult to recruit people with a commitment to addressing economic marginalisation.

Regarding the latter dimension of solidarity, five interviewees refer to the solidarity that exists between reuse social enterprises. Three interviewees note how the level of solidarity is strongest between reuse social enterprises dealing with the same type of discarded goods. One interviewee comments on how the level of collaboration is aided by the large size of the market. He believes that if the supply of discarded goods is lower, then this could lead to a lower level of solidarity. Two interviewees emphasise how solidarity between reuse social enterprises is driven by financial motives

\section{Discussion}

The principals of reuse social enterprises establish them primarily to achieve both social and environmental outcomes (Taylor, 2008). The research findings regarding motives for establishing reuse social enterprises are consistent with the literature. Some reuse social enterprises are initiated to meet a combination of environmental, economic and social justice objectives.

It is interesting to note the diversity of categories of organisations responsible for promoting reuse social enterprises. A high proportion of the cases were formed by local development companies. Indeed, this could be attributed to local development companies having adequate 
Table 4

Factors constraining reuse social enterprises becoming sustainable.

Internal factors constraining reuse social enterprise development

- Challenging behaviour of some staff that were formerly unemployed

- Personal issues of some staff adversely affect productivity

- Inadequate size of reuse facilities

- Location of facility can be remote and inhibits footfall
External factors constraining social enterprise development

- Restricted to employing lower skilled staff

- State funding, particularly labour subsidy, is insufficient.

- Insufficient social enterprise supports

- Inadequate state policy framework (reuse / social enterprise)

- Dominance of values associated with consumption and consumerism resources to establish reuse social enterprises compared to community development organisations which have experienced significant cuts in funding (Forde et al., 2017) In addition, due to Government policy, a number of community development organisations have become subsumed into local development companies (Harvey, 2012). Consequently, there is less likelihood of reuse social enterprises being formed by entities other than local development companies, other than those formed prior to the subsuming of community development organisations into local development companies. Therefore, if a local development company is not committed to establishing a reuse social enterprise, then there is less likelihood of a reuse social enterprise being formed in their catchment areas. To address this situation, the Department of Communications, Climate Action and Environment should oblige LDCs to establish reuse social enterprises.

The research identifies several obstacles and challenges encountered when developing reuse social enterprises. The table below (Table 4) details the internal and the external factors which constrain the development of reuse social enterprises (Medina Munroe and Belanger, 2017).

Furthermore, reuse social enterprises have to maintain an equilibrium between achieving their social mission and attaining financial sustainability (Mazzej, 2017). The research findings points to this requirement placing extra demands on both their governance structures and their management.

The research points to the necessity of reuse social enterprises accessing individuals with operational expertise. One of the key findings is that reuse social enterprises employ staff with expertise and skills relevant to their social enterprise activity. They perform a central role in the social enterprise both fulfilling its mission and achieving financial sustainability.

The research findings indicate that managers of reuse social enterprises require particular expertise and attributes to manage these businesses successfully. The capacity to forge relationships with a range of stakeholders is deemed critical to the social enterprise becoming sustainable. The findings point to the managers being committed individuals who exhibit tenacity and persistence in ensuring that their social enterprises realise their mission. Furthermore, for pragmatic and ethical reasons, the managers adhere to an inclusive style of leadership. The managers of social enterprises adhere to a different theory of leadership than investor owned-businesses (Ridley-Duff and Bull, 2016). Indeed, the research findings point to the inadequacy of mainstream theories of management in explaining the attributes and skills required by effective managers of reuse social enterprises (Murtagh, 2019). The implications for policy-makers is that leadership and management training for managers of investor-owned businesses is not sufficiently comprehensive to meet the range of skills and expertise required by managers of social enterprises. This would indicate the relevance of a new set of training programmes for managers of social enterprises. These training programmes would need to focus on the different styles of leadership practiced by managers of social enterprises, the range of issues they can encounter on a daily basis, and the skills required to forge relationships with a range of stakeholders.

With the exception of the support provided by some local development companies, there is a lack of support structures available to prospective promoters of reuse social enterprises. The new waste legislation from the Department of Communications, Climate Action and
Environment - which will transpose EU Waste Directive into Irish law should contain actions to support the development of reuse social enterprises. The Department of Communications, Climate Action and Environment should allocate additional funding to local development companies that demonstrate a commitment and capacity to support the development of reuse social enterprises. Indeed, local development companies that show a commitment to supporting the development of social enterprises should be awarded additional funding for this purpose. In addition, state funding should be allocated to community organisations committed to developing reuse social enterprises, particularly in areas where local development companies have not engaged in supporting social enterprise activity.

Both the Community Capital Framework (Emery, 2006) and Pringle's (2015) theoretical framework focus on the capacities required for the successful implementation of community initiatives. Although both are robust frameworks, when applied to Irish communities, they may require some modification to detail the capacities required to successfully implement reuse social enterprises. With regard to individual capacity, marginalised urban communities, tend to have a smaller cohort of individuals with the skills, knowledge and values to initiate reuse social enterprises. In relation to social capital, some communities, particularly socio-economically marginalised neighbourhoods, may not have the knowledge about how to engage with the local government system in order to secure both land and other resources to establish reuse social enterprises.

Both frameworks do not take account of the finding that the leadership and managers of reuse social enterprises need to have the capacity to forge relationships with local authorities, businesses and funding bodies, or that the reuse social enterprises also need to have access to individuals who possess key skills and expertise associated with the reuse of products.

With regard to infrastructural capacities, given that the demand for land is higher in urban than in rural settings, the framework needs to take account of the challenges in securing land and property in which to base reuse facilities. In relation to cultural capacity, the majority of communities would not have a history of developing reuse social enterprises. The values underpinning them include self-sufficiency, environmental and ecological sustainability. However, these values tend not to be prevalent in Irish communities. Indeed, the framework also does not place much emphasis on the values that exist among residents living in the catchment areas of the reuse social enterprises, as opposed to those that pertain to individuals active among reuse social enterprises. This is an important factor when one considers the dominance of consumerism in Irish society.

The theoretical framework could be broadened to acknowledge the critical importance of management style. In addition, it does not place much weight on the importance of community engagement. Innovation within the reuse social enterprise is viewed as being important to address the barriers encountered. Therefore, innovation should be also included in the framework.

\section{Conclusion}

There is a wealth of research which outlines the societal benefits of reuse social enterprises (Brennan and Ackers, 2003; Brook Lyndhurst, 2009; and Gutberlet, 2016). Therefore, it is incumbent on the Irish State 
to develop policies that assist communities to establish reuse social enterprises. These policy areas include procurement, the introduction of additional producer responsibility initiatives and altering the tax system to encourage reuse. In addition, a proportion of the Community Services Programme budget could be reserved for the establishment of reuse social enterprises.

Finally, research needs to be undertaken into policy needs to be changed and supporting practice. Regarding the former, research should focus on the social and economic benefits of reuse social enterprises to the State and to communities, and on the policy constraints in developing reuse social enterprises in Ireland. With respect to the latter, research could look at international best practice regarding policies for supporting the successful implementation of reuse social enterprises.

Perhaps the greatest challenge in the development of reuse social enterprises in Ireland (as well as social enterprises in general), is to address the pervasive culture of individualism and consumerism which has taken root in Irish society (Kirby, 2010). This cultural change will require a number of interventions over a lengthy period of time, by community organisations, trade unions and progressive political parties to demonstrate that an alternative Irish society is possible - where the benefits of the economy are not unequally distributed on the basis of class. One potentially effective measure would be to deliver an awareness campaign in schools, youth organisations, community organisations and third level institutions on the potency of social enterprise in addressing the many socio-economic issues that Ireland is encountering (Doyle, 2019).

\section{Funding}

The author is grateful to the ICOS Golden Jubilee Trust Fund for sponsoring his $\mathrm{PhD}$

\section{Declaration of interest}

None.

\section{References}

Ahmed, A., Ali, M., 2004. Partnerships for solid waste management in developing countries: linking theories to realities. Habitat Int. 28, 467-479. https://doi.org/10. 1016/S0197-3975(03)00044-4. Available from.

Ackerman, F., Mirza, S., 2001. Waste in the Inner City: asset or assault? Local Environ. 6 (2), 113-120. https://doi.org/10.1080/13549830120052764. Available from:.

Aiken, M., Slater, R., 2007. Feeling the squeeze? Tabbies or Tigers: the Case of Social Enterprises Contracting in the Fields of Recycling and Work Integration 4th Annual UK Social Enterprise Research Conference London South Bank University London.

Amin, A., Cameron, A., Hudson, R., 2002. Placing the Social Economy. Routledge, London and New York.

Amin, A. (Ed.), 2009. The Social Economy: The International Perspectives on Social Economic Solidarity. Zed Books, London and New York.

Aziz, L., Izaidin, A., Maizura, M., 2017. Exploring servant leadership instrument for social enterprise (Cooperative). Eur. J. Multidiscip. Stud. 2 (3), 7-24.

Belk, 2007. Why not share rather than own?'. Ann. Am. Acad. Pol. Soc. Sci. 611 (1), 126-140. https://doi.org/10.1177/0002716206298483. Available from:.

Bichard, E., 2006. A Better Way to Recycle (2006) A Better Way to Recycle: Co-operatives and Community Approaches to Recycling. Co-operative Action., Manchester.

Bocken, N., Olivetti, E., Cullen, J., Potting, J., 2017. Taking the circularity to the next level: a special issue on the circular economy. J. Clean. Prod. 21 (3), 476-482. https://doi.org/10.1111/jiec.12606. Available from:

Braun, V., Clarke, V., 2006. Using thematic analysis in psychology. Qual. Res. Psychol. 3 (2), 77-101. https://doi.org/10.1191/1478088706qp063oa. Available from:

Brennan, S., Ackers, S., 2004. Recycling best value and social enterprise: assessing the Liverpool model. Local Econ. 19 (2), 175-180. https://doi.org/10.1080/ 0269094042000208266. Available from:.

Brook Lyndhurst, 2007. Replicating Success: Social Enterprises \& the Waste Sector in London. Project WR0501/WRT 250 co-funded by DEFRA amd the London Development Agency under DEFRA'S Waste and Resources Evidence Programme. Defra, London.

Brook Lyndhurst, 2009. Household waste prevention: EU level review. L2-M4-I reuse and the Third Sector, Household waste prevention: EU level review. L2-M4-I reuse and the Third Sector. A Report for Defra's Waste and Resources Evidence Programme. Defra, London.

Chan, A., Ryan, S., Quarter, J., 2017. 'SUpported social enterprise: a modified social welfare organization. Non- Profit Vol. Sector Q. 46 (2), 261-279. https://doi.org/10.
1177/0899764016655620.

Collins, J., 2001. Good to great. Random House Business Books, London.

Connett, P., Sheehan, B., 2001. A Citizen's Agenda for Zero Waste: a United States/ Canadian Perspective. A Strategy That Avoids Incinerators and Eventually Eliminates Landfills. Grassroots Recycling Network. Community Recycling Network Australia, Bendigo, Victoria.

CWIN, 2016. Reuse in the UK and Ireland- a State of the Nations Report for the Chartered Institution of Waste Management. Chartered Institute of Waste Management., Marefair, Northampton.

Davies, A., 2002. Power, politics and networks: shaping partnerships for sustainable communities. Area 39 (2), 190-203. https://doi.org/10.1111/1475-4762.00071. Available from:

Davies, A., 2007. A wasted opportunity? Civil society and waste management in Ireland. Env. Polit. 16 (1), 52-72. https://doi.org/10.1080/09644010601073564. Available from:.

Dedehouanou, I., 1998. Coping with house waste management in Cotonou. Environ. Urban. 10 (2), 191-208. https://doi.org/10.1177/095624789801000208. Available from:.

Doyle, R., Davies, A., 2013. Towards sustainable household consumption: exploring a practice oriented, participatory backcasting approach for sustainable home heating practices in Ireland. J. Clean. Prod. 48, 260-271. https://doi.org/10.1016/j.jclepro. 2012.12.015. Available from.

Doyle, G., 2009. What Difference Does It Make? The Current and Potential Contribution of Social Enterprises to the Regeneration of Urban Disadvantaged Communities in the Republic of Ireland, Unpublished Dissertation for MSc in Local Development. University of Glasgow.

Doyle, G., 2019. Socialising economic development in Ireland: social enterprise an untapped resource. In: Maher, C. (Ed.), Value Creation for Small and Micro Social Enterprises. IGI Global, Hershey, PA.

EC (European Commission), 2011. Communication From the Commission to the European Parliament, the Council, the European Economic and Social Committee and the Committee of the Regions "Roadmap to a Resource Efficient Europe". COM(2011) 571 final. .

Ellen MacArthur Foundation, 2015. Towards a Circular Economy: Business Rationale for an Accelerated Transition. Ellen MacArthur Foundation., Cowes.

Ellen MacArthur Foundation, 2011. Resource Revolution; Meeting the World's Energy, Materials, Food and Water Needs. Ellen McArthur Foundation., Cowes.

Forde, C., O'Byrne, D., O'Connor, R., Ó hAdhmaill, F., Power, C., 2017. The Changing Landscape of Local and Community Development in Ireland: Policy and Practice. UCC, Cork.

Forfás, 2013. Social Enterprise in Ireland: Sectoral Opportunities and Policy Issues. Department of Enterprise, Trade and Employment., Dublin.

GHK, 2006. Social Enterprise - an International Literature Review. Small Business Service., London.

Gutberlet, J., 2008. Recovering Resources - Recycling Citizenship: Urban Poverty Reduction in Latin America. Routledge, London and New York.

Gutberlet, 2016. Urban Recycling Cooperatives: Building Resilient Communities. Routledge, London and New York.

Harvey, B., 2012. Downsizing the Community Sector: Changes in Employment and Services in the Community and Voluntary Sector in Ireland. Dublin. Irish Congress of Trade Unions Community Sector Committee.

Hines, F., Morley, A., Frater, L., Cartwrigh, S., Chandrashekar, S., 2008. A Model of Social Enterprise, Community Waste and Other Groups - Developing a Typology. Brass Research centre, Cardiff University.

Jackson, T., 2011. Prosperity without Growth. Economics for a Finite Planet. Earthscan, London.

Jackson, B., Nicoll, M., Roy, M., 2018. The distinctive challenges and opportunities for creating leadership within social enterprises. Soc. Enterp. J. 14 (1), 71-91. https:// doi.org/10.1108/SEJ-03-2017-0016.

King, M., Gutberlet, J., 2013. Contribution of cooperative sector recycling to greenhouse gas emissions Contribution of cooperative sector recycling to greenhouse gas emissions reduction: a case study of Ribeirão Pires, Brazil. Waste 33 (2271), -2780. https://doi.org/10.1016/j.wasman.2013.07.031. Available from:.

Luckin, D., Sharp, L., 2005. Exploring the community waste sector: are Sustainable Development and Social Capital useful concepts for project-level research'. Community Dev. J. 40, 62-75. https://www.jstor.org/stable/44258930.

Luckin, D., Sharp, L., 2003. Sustainable Development in Practice: Community Waste Projects in the UK. University of Bradford, Bradford.

Mason, C., Royce, M., 2008. Fit for purpose board development for social enterprise. Journal of finance and management in public services 6 (3), 57-67.

Mazzej, M., 2017. Different ways of dealing with tensions: practices of (re)negotiation in local social economies. Soc. Enterp. J. 13, 299-314. https://doi.org/10.1108/SEJ-07. 2016-0026.

Medina Munroe, M., Belanger, C., 2017. Analyzing external environment factors affecting social enterprise development. Soc. Enterp. J. 13, 138-152. https://doi.org/10.1108/ SEJ-06-2016-0021.

Middlemiss, L., Parrish, B., 2009. Building capacity for low-carbon communities: the role of grassroots initiatives. Energy Policy 38, 7559-7756. http://www.sciencedirect. com/science/article/pii/S0301-4215(09)00511-4.

Miller, S., McGloughlin, J., Gaillot, G., Connolly, L., 2017. Material Reuse Good Practice Guide. EPA, Dublin.

Molloy, A., Mc, Feely, Connolly, E., 2000. Building a Social Economy for the New Millennium. Guildhall Press, Derry.

Moreau, V., Sahakian, M., an Griethuysen, P., Vuille, F., 2017. Coming full circle: why social and institutional dimensions matter for the circular economy. J. Ind. Ecol. 21 (3), 497-506. https://doi.org/10.1111/jiec.12598. Available from: 
Nicholls, A., 2006. Social Entrepreneurship: New Paradigms of Sustainable Social Change. Oxford University Press, Oxford.

Nicholls, A., Teasdale, S., 2017. Neo-liberalism by stealth? Exploring continuity and change within the UK social enterprise policy paradigm. Policy Polit. 45 (3), 323-341. https://doi.org/10.1332/030557316X14775864546490.

Price, J., Joseph, J., 2000. Demand management- a basis for waste policy: a critical review of the applicability in terms of achieving sustainable waste management'. Sustain. Dev. 8 (2), 96-105. https://doi.org/10.1002/(SICI)1099-1719(200005) 8:2\%3C96::AID-SD133\%3E3.0.CO;2-J. Available from:

Pongracz, E., Pohjola, V., 2004. Re-defining waste, the concept of ownership and the role of waste management. Resour. Conserv. Recycl. 40, 141-153. https://doi.org/10. 1016/S0921-3449(03)00057-0. Available from:.

Pringle, R., 2015. Moving Towards Whole Settlement Energy Self- Sufficiency in Rural Communities. Unpublished $\mathrm{PhD}$ dissertation in Newcastle University. .

Resource Futures, 2009. Understanding Waste Growth at Local Authority Level. Resource Futures, Bristol.

Ridley- Duff, R., Bull, M., 2016. Understanding Social Enterprise: Theory and Practice.
Sage, London.

Seanor, P., Bull, M., Baines, S., Ridley-Duff, R., 2013. Narratives of transition from social to enterprise: you can't get there from here!. Int. J. Entrep. Behav. Res. 19 (3) pp. 324-4.

Steel, B., 1996. Thinking globally and acting locally?: environmental attitudes, behaviour and activism. J. Environ. Manage. 47, 27-36.

Taylor, E., 2008. Building community with recycling: a case of two small islands in British Columbia Canada. Masters of Arts in the Department of Geography, University of Victoria.

Van Dierendonck, D., Nuijten, I., 2011. Servant leadership: a review and synthesis. J Manage. 37, 1228-1261.

Vickers, I., 2010. 'Social Enterprise and the Environment: a Review of the Literature' Working paper, no.22, Third Sector Research Centre.

Yousefpour, N., Barraket, Jo., Furneaux, Craig W., 2012. A Baseline Study of Australia's Community Recycling Enterprises (CRE). Community Recycling Network Australia Website. This file was downloaded from. ACPNS, Australia. https://eprints.qut.edu. $\mathrm{au} / 58916 /$. 